\title{
Scientific and Artful Voices of Resilience
}

\author{
Pallavi R. Devchand * \\ Department of Physiology and Pharmacology, Cumming School of Medicine, University of Calgary, Calgary, AB, Canada
}

Resilience is a fluid trait that is triggered by personal experience. It is, arguably, a necessity for a scientist. What is it? You know it, when you see it. One thing is for certain: resilience reflects the dynamic toggle between change and an individual's identity.

Keywords: systems biology, inflammation, Al, resilience, rare disease

“Nobody knows me, but I'm always there.

A statistic, a reminder of a world that doesn't care"

- UB40 in One in Ten, 1981

\section{OPEN ACCESS}

Edited by:

Paola Patrignani,

University of Studies G. d'Annunzio

Chieti and Pescara, Italy

Reviewed by:

Patrizia Ballerini,

University of Studies G. d'Annunzio

Chieti and Pescara, Italy

Pietro Minuz,

University of Verona, Italy

*Correspondence:

Pallavi R. Devchand

Pallavi.Devchand@ucalgary.ca

Specialty section:

This article was submitted to Inflammation Pharmacology,

a section of the journal

Frontiers in Pharmacology

Received: 21 April 2021

Accepted: 06 May 2021

Published: 26 May 2021

Citation:

Devchand PR (2021) Scientific and

Artful Voices of Resilience.

Front. Pharmacol. 12:698567.

doi: 10.3389/fphar.2021.698567
In the early 1990s, young Alan Wolffe would regularly hop on a flight from DC to the Canadian Rockies. He was test-driving his research: touting the delicate roles of nucleosome positioning in the fine-tune regulation of transcription. In those days of yore, the topic was debatable. And frankly, students in Calgary were perplexed by his energy. Here was a witty Englishman who reveled in facing a critical Calgarian crowd, knowing that the last question to him would always be the same riddle. Even when he was armed with beautiful data using the estrogen receptor activity on the vitellogenin gene of Xenopus laevis (Schild et al., 1993), the riddle was still asked and remained unanswered. Alan had more than data in his arsenal. He was a prolific, competitive and effective communicator - obsessed with a mission. Today, Alan's spirit reflects in the casual acceptance of his science - I imagine he would have quipped at the business of histone regulation. How did the man fuel simple "beads-on-a-string" into a science fad that rocketed to potential of clinical relevance?

We call it customary - the passage of habits and food from one generation to another. Fascinating! to follow documented trails from the Egyptians Papyrus (Ebbell, 1937) to Guido Majno's Healing Hand (Majno, 1975); or from a monk's letter (Stone, 1763) to Nobel prizes (Bergstrom et al., 1982). Have you heard the English gentleman (Flower, 2013) challenge Shakespeare's potions? Not everyone is a foodie. Louis Thomas spun biological tales of Medusa and the Snail (Thomas, 1974). And Gerry Weissman - oh my! - he will essay you deep into science of the humanities (Weissmann, 2006-2016). Wanna get out some? Steven J. Gould pairs well with a $22 \mathrm{~km}$ hike to a soft quarry in the Canadian Rockies (Gould, 1990). And if you are up for a laugh, Uncle Syd will tickle you sarcastic with his seven deadly sins (Brenner, 2019). Of course, you could simply bide time with Alan Lightman (2004). Why is it that despite Nobel prizes and landmark discoveries, these men created bandwidth for communicating their (lesser) passions?

Precious insights come from personal journeys. Paul Allen (2012) and Max Perutz (2002) remind us that even the most famous scientists are fated by human interactions. Oliver Sacks (2015) and Peter Bach (2011) went to a newspaper and won the hearts of so many suffering in silence. Mesmerizing blockbuster movies limelight our global responsibilities and gaping loopholes in our system. Constant Gardener (2005), Ex Machina (2014), Side Effect (2013), Eye in the Sky (2015), Little Boy and Fat Man (1989) rightfully message, "Kudos for inventing something, but - "

You bet! There are many vested interests in the businesses of health (Devchand, 2019a). Who can ignore the bloody unicorns (Carreyrou, 2018) or the painful ones (Keefe, 2021)? There is an art to 
busting open a new field and influencing the culture and direction of medicine (FitzGerald, 2005; Schadt, 2005; Devchand et al., 1999). Luckily, we have a narrative of the beginning of Biotech (Hughes, 2013), an award-winning movie that institutionalized multi-scale biology as (The New Biology, 2011), and a vision for artificial intelligence to increase empathy in medicine (Topol, 2019; Devchand, 2019b). Increasingly, patient advocates seed and sustain their missions. What do you do when you are statistically disadvantaged because your disease is rare rather than common? One man's trip with Castleman disease cracks open a cytokine storm of research with a global reach (Fajgenbaum, 2019).

In all tales, change comes with a resilient voice of awareness:

\section{“And I'll tell it and think it and speak it and breathe it And reflect it from the mountains So all souls can see it" - Bob Dylan in The Freewheelin', 1963}

\section{REFERENCES}

Allen, P. (2012). Idea Man: A Memoir by the Cofounder of Microsoft. New York City: Penguin Books.

Bach, P. (2011). Well Blog. New York: New York Times.

Bergstrom, S. K., Samuelsson, B. I., and Vane, J. R. (1982). Nobel Prize in Medicine. Available at: https://www.nobelprize.org/prizes/medicine/1982/ summary/ (Accessed April 20, 2021).

Brenner, S. (2019). Loose ends. ..False Starts. Singapore: World Scientific.

Carreyrou, J. (2018). Bad Blood: Secrets and Lies in a Silicon Valley Startup. New York City: Knopf.

Constant Gardener (2005). (based on Novel by John Le Carré) Potboiler Productions, London.

Devchand, P. R., Hihi, A. K., Perroud, M., Schleuning, W. D., Spiegelman, B. M., and Wahli, W. (1999). Chemical Probes that Differentially Regulate Peroxisome Proliferator-Activated Receptor Alpha and BLTR, Nuclear and Cell Suface Receptors for Leukotriene B4. J. Biol. Chem. 274 (13), 23341-23348. doi:10.1074/jbc.274.33.23341

Devchand, P. R. (2019a). It Is Personal - or Not!. Egypt. J. Basic Clin. Pharmacol. 9, 101416-101417. doi:10.32527/2019/101416

Devchand, P. R. (2019b). Well. From Artificial Intelligence to Empathy? Nucl. Receptor Res. 6, 101436. doi:10.32527/2019/101436

Ebbell, B. (1937). The Papyrus Ebers: The Greatest Egyptian Medical Document. Copenhagen: Levin and Munksgaard.

Ex Machina (2014). Film4 DNA Films, London.

Eye in the Sky (2015). Eye in the Sky. London: Entertainment One.

Fajgenbaum, D. (2019). Chasing My Cure: A Doctor's Race to Turn hope into Action. New York: Ballantine Books.

FitzGerald, G. A. (2005). Anticipating Change in Drug Development: the Emerging Era of Translational Medicine and Therapeutics. Nat. Rev. Drug Discov. 4 (10), 815-818. doi:10.1038/nrd1849

Flower, R. (2013). Shakespeare's Medicine Cabinet. IGMB Personal Highlights Series@ Mount Sinai. Available at: https://www.frontiersin.org/events/ Shakespeare_s_Medicine_Cabinet/2139 (Accessed April 20, 2021).

Gould, S. J. (1990). Wonderful Life: The Burgess Shale and the Nature of History. New York: W.W. Norton and Company.

Hughes, S. S. (2013). Genentech: The Beginnings of Biotech (Synthesis). Chicago: University of Chicago Press.

\section{DATA AVAILABILITY STATEMENT}

The original contributions presented in the study are included in the article/Supplementary Material, further inquiries can be directed to the corresponding author.

\section{AUTHOR CONTRIBUTIONS}

The author confirms being the sole contributor of this work and has approved it for publication.

\section{FUNDING}

PRD was funded in part as K.A.S.H. Research Scientist in Preventative Medicine, with support from NIH (AR002218), the CADgenomics consortium (Leducq Foundation) and the PENTACON consortium (NIH HL117798).

Keefe, P. R. (2021). Empire of Pain: The Secret History of the Sackler Dynasty. New York City: Doubleday.

Lightman, A. (2004). Einstein's Dreams. New York City: Vintage Books.

Little Boy and Fat Man (1989). Little Boy and Fat Man. Los Angeles: Paramount Pictures.

Majno, G. (1975). The Healing Hand: Man and Wound in the Ancient World. Boston: Harvard University Press.

Perutz, M. (2002). I Wish I Had Made You Angry Earlier (Essays on Science, Scientists and Humanity). Long Island, NY: Cold Spring Harbour Laboratory Press.

Sacks, O. (2015). My Periodic Table. New York: New York Times Opinion.

Schadt, E. E. (2005). Exploiting naturally occurring DNA variation and molecular profiling data to dissect disease and drug response traits. Curr. Opin. Biotechnol. 16 (6), 647-54. doi:10.1016/j.copbio.2005.10.005

Schild, C., Claret, F. X., Wahli, W., and Wolffe, A. P. (1993). A Nucleosomedependent Static Loop Potentiates Estrogen-Regulated Transcription from the Xenopus Vitellogenin B1 Promoter In Vitro. EMBO J. 12 (2), 423-433. doi:10.1002/j.1460-2075.1993.tb05674.x

Side Effect (2013). Endgame Entertainment, Northbrook.

Stone, E. (1763). An Account of the success of the Bark of Willow in the Cure of Agues. Philos. Trans. R. Soc. 53, 195-200.

The New Biology (2011). (directors: John Rubin, Eric Schadt, Glenn Farrell) PacBio. Available at: https://www.youtube.com/watch?v=sjTQD6E3lH4 (Accessed April 20, 2021).

Thomas, L. (1974). Medusa and the Snail: More Notes of a Biology Watcher. New York: Penguin Books.

Topol, E. J. (2019). Deep Medicine: How Artificial Intelligence Can Make Healthcare Human Again. New York: Hachette Book Group Inc.

Weissmann, G. (2006-2016). Editorials in FASEB Journal, Hoboken.

Conflict of Interest: The author declares that the research was conducted in the absence of any commercial or financial relationships that could be construed as a potential conflict of interest.

Copyright (c) 2021 Devchand. This is an open-access article distributed under the terms of the Creative Commons Attribution License (CC BY). The use, distribution or reproduction in other forums is permitted, provided the original author(s) and the copyright owner(s) are credited and that the original publication in this journal is cited, in accordance with accepted academic practice. No use, distribution or reproduction is permitted which does not comply with these terms. 